ceutical sciences, or in botany in relation to medicine; the Breant prize (100,000 francs), for the discovery of a specific cure for Asiatic cholera, or for the discovery of its vause, such that the epidemic can be suppressed. If neither of these be forthcoming, the interest on the capital sum will be given for a rigorous demonstration of the presence in the air of substances playing a part in the propagation of epidemic diseases. The Godard prize (rooo francs), for a memoir on the anatomy, physiology, or pathology of the genito-urinary organs; the Lallemand prize (1800 francs), for the encouragement of work relating to the nervous system; the Baron Larrey prize ( 750 francs), for a work on military medicine, surgery or hygiene; the Bellion prize (1400 francs) and the Mege prize (I0,000 francs), for an essay on the causes which have retarded or favoured the progress of medicine from antiquity to the present day.

In physiology, a Montyon prize (750 francs), for a work in experimental physiology; the Philipeaux prize (900 francs); the Pourat prize (Iooo francs), for a study of the physical and chemical changes in respiration induced by high altitudes; and the Martin-Damourette prize (I400 francs), for a work on therapeutical physiology.

Among the general prizes are the Arago medal; the Lavoisier medal and the Berthelot medal; the Montyon prizes (unhealthy trades, 2500 francs and ${ }^{5} 500$ francs), for a discovery ameliorating the condition of an unhealthy trade ; the Wilde prizes (4000 francs, or two of 2000 francs), for a discovery in astronomy, physics, mineralogy, geology or experimental mechanics; the Tchihatchef prize (3000 francs), for exploration in Asia; the Leconte prize (50,000 francs), for a capital discovery in mathematics, physics, chemistry, natural history or medicine; the Jean-Jacques Berger prize ( 15,000 francs), for a work on Paris; the DelalandeGuérineau prize (rooo francs); the Jerome Ponti prize (3500 francs); the Houllevique prize (50oo francs); the Cahours prize (3000 francs), for researches in chemistry; the Saintour prize (3000 francs); the Trémont prize (3000 francs); the Gegner prize ( 3800 francs); and the Lannelongue prize (1200 francs)

Among these, the prizes bearing the names of Lalande, Desmazières, Lavoisier, Wilde, Tchihatchef, and Leconte will be awarded without distinction of nationality.

\section{RESEARCH GRANTS OF THE CARNEGIE INSTITUTION.} A LIST of the grants in aid of scientific investigations
made by the Carnegie Institution during the fiscal year 1903 is given below. The amount set apart as grants for research during that period was 40 ,oool. From the beginning of the Institution to the end of October, 1903, the number of applications for grants was 1042 , and the total sum asked for by the 406 applicants who stated the amount desired was more than 440 ,oool. In addition, the advisory committees recommended grants amounting to 182 , 3ool., so that the total sum asked for was about $622,300 l$. It will be evident fromi this that the present income of the Carnegie Institution can only provide for a small part of the grants requested. The grants made are as follows :-

Anthropology.-For ethnological investigation among the Pawnees, Dr. G. A. Dorsey, Field Columbian Museum, Chicago, Ill., 50ol.; for obtaining evidence relative to the early history of man in America, Dr. Wm. H. Holmes, director Bureau of American Ethnology, Washington, D.C.' $400 l$. ; to investigate the precious stones and minerals used in ancient Babylonia in connection with the investigation of Mr. William Hayes Ward, Mr. George F. Kunz, New York City, rool.; for study of oriental art recorded on seals, \&c., from western Asia, Dr. William Hayes Ward, New York City, $300 l$.

Astronomy.--For astronomical observations and computations, Prof. Lewis Boss, Dudley Observatory, Albany, N.Y., 10ool.; for investigating proposal for a southern and a solar observatory, Profs. Boss, Hale and Campbell, Ioool.; for pay of assistants to take part in researches at the Lick Observatory, Prof. W. W. Campbell, Lick Observatory, Mt. Hamilton, Cal., 8ool. ; for a new reduction of Piazzi's star observations, Prof. Herman S. Davis,
Gaithersburg, Md., Iool.; for measurements of stellar parallaxes, solar photographs, \&c., Prof. George E. Hale, Yerkes Observatory, Williams Bay, Wis., 8ool.; for determining the elements of the moon's motion and testing the law of gravity, Prof. Simon Newcomb, Washington, D.C., $600 l . ;$ for study of the astronomical photographs in the collection of Harvard University, Prof. E. C. Pickering, Harvard University, Cambridge, Mass., 50ol. ; for pay of two assistants to observe variable stars, Prof. Wm. M. Reed, Princeton Observatory, Princeton, N.J., 20ol. ; for measurement of astronomical photographs, \&c., Miss Mary W. whitney, Vassar College, Poughkeepsie, N.Y., zool.

Bibliography-For preparing and publishing the "Index Medicus," Dr. Robert Fletcher, Army Medical Museum, Washington, D.C., zoool.; for preparing and publishing a "Handbook of Learned Societies," Mr. Herbert Putnam, Librarian of Congress, Washington, D.C., roool.

Botany.-For investigation of plant hybrids, Mr. W. A. Cannon, New York Botanical Garden, N.Y., Iool.; for study of types of water-lilies in European herbaria, Mr. H. S. Conard, University of Pennsylvania, Philadelphia, 6ol.; Desert Botanical Laboratory (Mr. F. V. Coville and Mr. D. T. MacDougal, Washington, D.C.), $1600 l$.; researches on the cytological relations of the Amobæ, Acrasieæ and Myxomycetes, Mr. E. W. Olive, Crawfordsville, Ind., 20ol.; for preliminary studies on the Philippine flora, Dr. Janet Perkins, working at the Royal Botanical Gardens, Berlin, Germany, $380 l$.

Chemistry.-For a systematic chemical study of alloys, beginning with the bronzes and brasses, Prof. W. D. Bancroft, Cornell University, Ithaca, N.Y., rool.; for investigation of the rare earths, Prof. L. M. Dennis, Cornell University, Ithaca, N.Y., 20ol.; for investigations in physical chemistry, Prof. H. C. Jones, Johns Hopkins University, Baltimore, Md., 2ool.; for researches on osmotic pressure, Prof. H. N. Morse, Johns Hopkins University, Baltimore, Md., $300 l$. ; for certain chemical investigations, Prof. A. A. Noyes, Massachusetts Institute of Technology, Boston, Mass., 4ool.; for investigation of values of atomic weights, \&c., Prof. Theo. W. Richards, Harvard University, 500 . ; for continuing investigations on the derivatives of camphor and allied bodies, Mr. J. Bishop Tingle, Illinois College, Jacksonville, Ill., rool.

Engineering.-For experiments on ship resistance and propulsion, Prof. W. F. Durand, Cornell University, Ithaca N.Y., $824 l$; for study of aluminium bronzes, Mr. Leonard Waldo, New York City, gool.

Exploration.-For preliminary examination of the transCaspian region, Mr. Raphael Pumpelly, Newport, R.I. $\mathrm{r} 300 \mathrm{l}$.

Geophysics.-For investigating the flow of rocks, Prof. Frank D. Adams, McGill University, Montreal, 5ool. ; for investigating the subject of geophysical research, \&c., Prof. C R. Van Hise, University of Wisconsin, Madison. Wis. $500 l$.

Geology.-For study of the fundamental principles of geology, Prof. 'T. C. Chamberlin, University of Chicago Chicago, Ill., r2ool.; for geological exploration in eastern China, Mr. Bailey Willis, U.S. Geological Survey, Washington, D.C., $2400 l$.

History.-For an examination of the historical archives of Washington, Mr. Worthington C. Ford, Library of Congress, Washington, D.C., $400 l$.

Palaeontology.-For continuation of work on the morphology of Permian reptiles, Prof. E. C. Case, State Normal School, Milwaukee, Wis., rool.; for monographing the fossil Chelonia of North America, Dr. O. P. Hay, American Museum of Natural History, $440 \mathrm{l}$.; for continuation of his researches on living and fossil cycads, Dr. G. R. Wieland, Yale University, New Haven, Conn., 3ool.; for preparing a monograph on the Plesiosaurian group, Prof. S. W. Williston, University of Chicago, Chicago, Ill., I6ol.

Physics.-For study of certain arc spectra, Prof. Henry Crew, Evanston, I11., 20ol.; for aid in ruling diffraction gratings, Prof. A. A. Michelson, University of Chicago, I11., $300 l . ;$ for experiments on the magnetic effect of electrical convection, Dr. Harold Pender, Johns Hopkins University, Baltimore, Md., ${ }^{1} 5 \mathrm{ol}$; f for research, chiefly on the theory of light, Prof. R. W. Wood, Johns Hopkins University, Baltimore, Md., $200 l$. 
Physiology.-For experiments in nutrition, Prof. W. O. Atwater, Wesleyan University, Middletown, Conn., Ioool.; for preparing report on the physiology of nutrition, Dr. Arthur Gamgee, Montreux, Switzerland, 13ool.

Psychology.-For certain investigations on the anthropology of childhood, Dr. G. Stanley Hall, Clark University, Worcester, Mass., 40ol.; for researches in experimental phonetics, Prof. E. W. Scripture, Yale University, New Haven, Conn., $320 l$.

Zoology.-For determining the laws of variation and inheritance of certain Lepidoptera, Dr. H. E. Crampton, Columbia University, New York, $50 l$.; for investigation of recent and fossil corals, Dr. J. E. Duerden, Chapel Hill, N.C., $200 l$.; for investigating the blind fishes of Cuba, Dr. C. H. Eigenmann, Indiana University, Bloomington, Ind., $200 l$.; for preparing manuscript and illustrations for a monograph on American mosquitoes, Dr. L. O. Howard, Department of Agriculture, Washington, D.C., 40ol.; for experiments on the behaviour of lower animals, Dr. H. S. Jennings, University of Michigan, Ann Arbor, Mich., 5ol.; to making a comparative study of the spermatogenesis of insects and other classes of arthropods, and if possible to determine the specific functions of the different chromosomes, Prof. C. E. McClung, Kansas University, Lawrence, Kans., rool. ; for investigations in experimental embryology, \&c., in Naples, Dr. E. B. Wilson, Columbia University, New York, 2ool. ; for morphology and classification of deep sea sponges, Prof. H. V. Wilson, University of North Carolina, Chapel Hill, 2ool.; for maintenance of twenty tables, Marine Biological Laboratory, Woods Hole, Mass., $2000 l$.; for maintenance of two tables, Marine Biological Station, Naples, Italy, $200 l$.

\section{SURVEY OF SCOTTISH LAKES.}

$R$ EADERS of NATURE are aware that in the year $1896 \mathrm{Sir}$ John Murray and the late Mr. Fred. P. Pullar commenced to carry out a bathymetrical survey of the fresh-water lochs of Scotland, but the work was brought to a standstill in February, Igor, owing to the tragic death of the younger collaborator, who heroically lost his life in attempting to save others in an ice accident on Airthrey Loch, near Bridge of Allan. As a memorial to this talented young man, his father, Mr. Laurence Pullar, and Sir John Murray resolved to complete this important piece of work at their joint expense, and in the spring of 1902 the survey was resumed under the personal supervision of Sir John Murray, with the assistance of a staff of young scientific men.

During the season of 1902 one hundred and fifty-five Scottish lakes were completely surveyed, and during the past season two hundred and thirty-one, making a total of three hundred and eighty-six of the Scottish fresh-water lochs completed, including all the larger and more important ones. There still remain, however, a good many small and outlying lochs to be surveyed, but it is anticipated that early next season (1904) the actual work of sounding the Scottish fresh-water lochs so far as practicable will be completed. The preparation of the maps for the engraver has been going on continuously, and the publication of the results of the survey has already been commenced in the Geographical Journal and the Scottish Geographical Magazine.

In continuation of the work of Sir John Murray and the late Mr. Pullar among the lochs of the Forth and Tay basins, the staff of the Lake Survey commenced operations early in 1902 in the northern portion of the Tay basin, and

1 The field staff consisted of Mr. T. N. Johnston, first assistant and zoologist; Mr. James Parsons, chemist; Mr. T. R. H Garrett, geologist Mr. John Hewitt, zoologist ; Mr. James Murray, assistant zoologist : and the following gentlemen took part in the field work for longer or shorter periods during the summer of $\mathrm{rgO2}$, viz. Mr. R. M. Clark, Dr. J. Sutherland

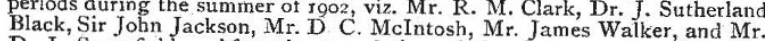
D. J. Scourfield. After the completion of the first season's work, Mr. Parsons and Mr. Garrett received appointments in Ceylon and Borneo Parsons and $\mathrm{Mr}$. Garrett received appointments in Ceylon and Borneo
respectively, and their places on the staff were taken by Mr. R. B. Young respectively, and their places on the staff were taken by Mr. R. B. Young
and Mr. R. C. Marshall ; in addition, Mr. E. R. Watson and Mr. E. M. Wedderburn joined the staff early in 1903 , and in July, when Mr. Young left to take up an appointment in the South African College, Mr. J. H. M. Wedderburn tnok his place on the staff. The office work in Edinburgh is in charge of Mr. James Chumley, secretary and subeditor, with the assistance of Mr. Robert Dykes.

$$
\text { No. } 1784 \text {, voL. } 09]
$$

after surveying the principal lochs in that neighbourhood moved northwards and westwards through Perthshire, Inverness-shire, Argyllshire, Ross-shire, Sutherlandshire, and Caithness-shire, sounding all the more important lochs, like Lochs Tay, Rannoch, Treig, Laggan; Arkaig, Shiel, Morar, Maree, Fannich, Shin, Assynt, More, Naver, Loyal, Hope, and many smaller ones. In the spring of I903 a start was made with the lochs of the Caledonian Canal (Ness and Lochy) and of the surrounding district, then the staff moved southwards to Loch Awe and Loch Lomond, which were sounded for the sake of comparison with the surveys carried out by the Admiralty in the year 180x. Subsequently the staff was split up into small parties, one party proceeding to the south of Scotland to survey Lochs Doon, Ken, Dee, \&c., a second party proceeding to Lewis to survey Loch Langavat and other smaller lochs, while a third party proceeded to Orkney and Shetland to survey Lochs Harray and Stenness, and the numerous small lochs in those islands.

In addition to the routine sounding work, continuous observations of a varied description have been carried out on Loch Ness throughout the past season. In order tc study the seiches in Loch Ness, a limnograph, constructed in Geneva under the supervision of Dr. Ed. Sarasin, was set up in the grounds of St. Benedict's Monastery at Fort Augustus (by kind permission of the Lord Abbot), and has been in charge of $\mathrm{Mr}$. E. M. Wedderburn. The records obtained are now being studied and classified, and are likely to lead to interesting results; uninodal, binodal, and multinodal seiches have been recognised, and their duration, periodicity, and amplitude determined.

Continuous observations of the temperature of the water at different depths in Loch Ness have also been carried on by Sir John Murray, Mr. Watson, and other members of the staff since July. The temperature changes have been studied systematically-first, by mean's of platinum resistance thermometers with Callendar's recording apparatus, installed by the Cambridge Scientific Instrument Co., at a cost of several hundred pounds, from a yacht anchored in 300 feet of water off Fort Augustus, and connected with the shore by an electric cable; secona, by means of ordinary reversing thermometers at Fort Augustus and from a steam yacht, which during several weeks made numerous cruises throughout the length of the loch. Difficulties have cropped up with reference to the working of the electrical thermometers, but the observations made thus far have shown that the waters in Loch Ness are in constant motion, even down as far as 300 to 400 feet. The motion of the upper waters it Scottish lochs has been already studied by Sir John Murray, who advanced the theory that a wind blows the surface water before it, and so causes a slope of the upper isothermals down towards the lee shore. The investigations in Loch Ness confirm this theory, whilst adding some restrictions for this particular case. But the chief interest attaches to the study of the motion of the deeper isotherms, which have never before been studied with care. These isotherms have been found to be swinging in a periodic fashion, with a natural period of about three days. It is supposed that we have here an internal seiche, with the separating surface determined by the greatesi change of temperature with depth, the restoring force being given by the difference of density between the warmer upper and the colder deeper waters. The investigations indicate that this internal seiche is started by gales or winds of a strength above the average.

Many biological observations have also been made in Loch Ness and neighbouring lochs by $\mathrm{Mr}$. James Murray, $\mathrm{Mr}$ Scourfield and others, by means of various kinds of townets and drag-nets, with the view of obtaining some insight into the relation between the habits and distribution of the different planktonic and benthonic organisms and the varying physical conditions.

All these limnological investigations have been carried out under the immediate superintendence of Sir John Murray, who took up residence at Fort Augustus from the beginning of July until the end of October, and arrangements have been made for the continuance of the temperature and seiche observations under the charge of $\mathrm{Mr}$. Watson, and of the biological observations under the charge of Mr. James Murray, throughout the winter. 